\title{
4-4 走査トンネル顕微鏡(STM)
}

\section{保 坂 純 男}

\section{1. まえがき}

計測装置における永遠の課題は高分解能化, 高感度 化および高速化である. 顕微鏡の世界においてもこれ らの追及が行われている. 特に, 高分解能化は光学顕 微鏡から電子顕微鏡へと発展する過程において, sub $-\mu \mathrm{m}$ から sub-nm オーダへと改良されてきた。しか し, 高分解能化を進めるためにはどうしても超えなけ ればならない壁がある. Abbe の壁である。これは， 1900 年以前にビームのスポット径が光の回折により 波長の半分以下には絞ることができないと Abbe によ って予測された限界である。

電子顕微鏡においては, 波長を短くすることにより 高分解能化を進めることはできたが, Abbe の壁を超 えることはできなかった。しかし，このAbbe の壁を 打ち破る顕微鏡が最近開発された. 1983 年に発表さ れたSTM (Scanning Tunneling Microscope) $)^{1)}$ であ る.

STM は, 固体プローブを試料に接近するだけで, あまりにも高分解能の像が得られるゆえ, 活発にマイ クロエレクトロニクス材料の評価への応用が行われて いる.ここでは STM の歴史的意義, その原理, およ び応用例として，その場（in-situ）観察と複合計測例 について述べる.

\section{STM の歴史的背景と皇義}

STM の原形は 1971 年に NBS の R. Young ら 2 に よって発表された Topografinerである.これはス夕 イラスを用いた 3 次元形状測定の高解像化を狙った技 術であった。彼らはトンネル電流を用いず, 電界放射 電流を用いたが, 論文ではトンネル電流を用いること により原子オーダあるいはそれ以下の分解能を得るこ とができると提案していた。しかし，この提案が実現 されたのは 1983 年 IBM の G. Binnig, H. Rohrer ら によってである ${ }^{1)}$. 実に, 12 年後のことである.

\section{$\dagger$ 株式会社日立製作所 中央研究所}

"Scanning Tunneling Microscope" by Sumio Hosaka (Central Research Laboratory, Hitachi Ltd., Tokyo)
一方，当初からAbbe の壁を超えることを目的とし た研究の流れは別にあった. 1956 年に J. A. O'Keefe によって走查型近視野顕微鏡の概念が提案されてい た、これは小さなアパーチャを用いて試料に接近する と, 波長に依存しない高分解能の像が得られるという ことであった。これを実験的に初めて示したのは， 1972 年, London大学の E. H. Ash らである ${ }^{3)}$.ここ では, $10 \mathrm{GHz}$, 波長 $3 \mathrm{~cm}$ の電磁波を用い, $1.5 \mathrm{~mm}$ 径のアパーチャで $0.5 \mathrm{~mm}$ 幅のラインアンドスペース パターンを解像している.これは波長の $1 / 60$ の分解 能を実現したことを示した.

その後, IBM のU. Durig, H. Rohrer らはArレ ーザ光 (488 nm)を用いて $20 \mathrm{~nm}$ の分解能を得た ${ }^{4)}$. 彼 らはこの顕微鏡を NFOS (Near Field Optical Scanning microscopy) と呼び, 原理は小さなピンホール を通過することができるエバネセント波を利用してい る。

以上のように小さなピンホール(アパーチャ)が, 得 られる像の分解能を決めている。しかし, 原子オーダ の分解能を得るためには原子オーダのアパーチャの加 工が必要である.この加工は不可能に近い. STM は この小さなアパーチャをトンネル現象を利用すること によって容易に実現している.

\section{3. 計 測 原 理}

STM の計測原理図を図 1 に示す. STM は図 1 の ように探針を試料に約 $10 \AA$ 程度接近し，その間に印 加したバイアス電圧 $V$ により流れるトンネル電流を 利用している.このトンネル電流を一定に保つように サーボ制御系抢よび圧電素子により探針を制御し，さ らに, 2 次元走査することにより, STM は非接触で 試料表面の 3 次元情報を得ることができる. 3 次元情 報は，探針を駆動する圧電素子の動きから得ている． 計測分解能は原子オーダあるいはそれ以下が得られ る。これは，(1)式のように，トンネル電流 $I$ が間 隙 $s$ に対して指数関数的に変化するトンネル現象を利 用しているからである5).

$$
I \approx s^{-1} \exp (2-s / \lambda)
$$




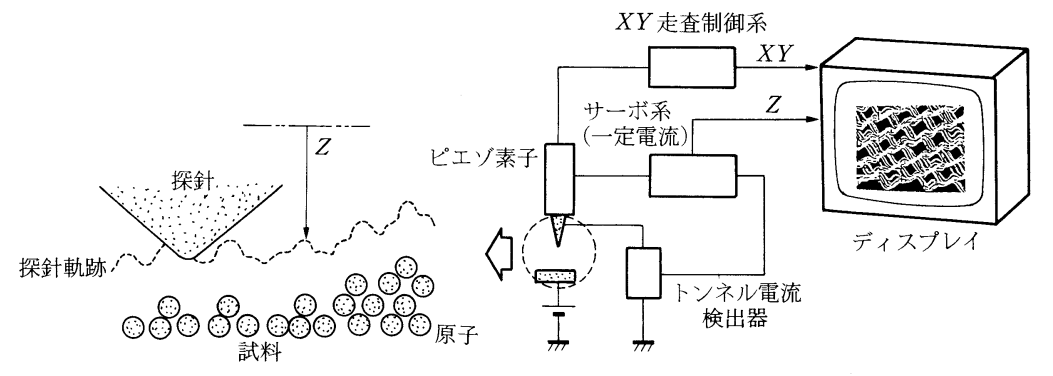

図 1 STM 測定原理図

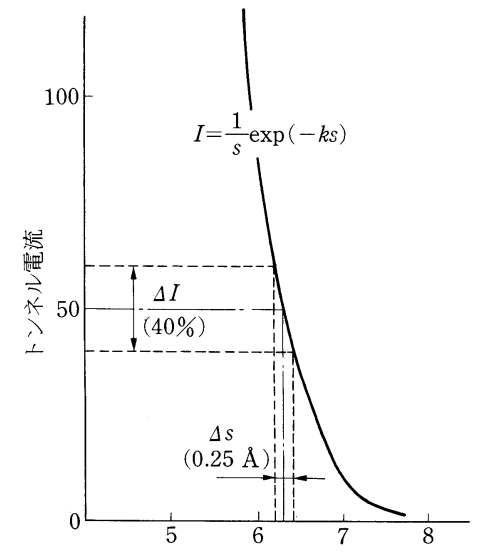

トンネル間隙 $s(\AA)$

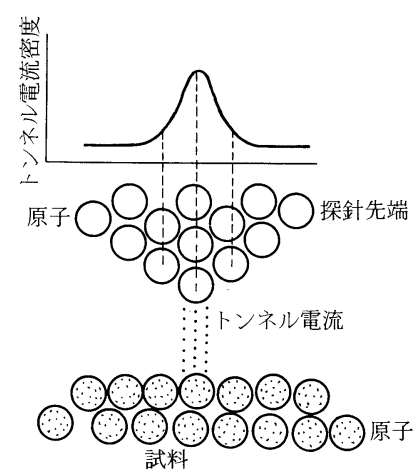

(b) $X Y$ 面内分解能 （分布図はトンネル電流の空間分布）

(a) $Z$ 方向の分解能

(サーボエラーが $40 \%$ の時, 間隙誤差 $0.25 \AA$ )

図 2 STM 分解能説明図

ただし, $\lambda=\left((2 \pi / h)^{2} 2 m \psi\right)^{-1 / 2}$ は試料の表面波動関数 の試料外減衰距離, $m$ は電子質量, $\phi$ はトンネル障 壁である. 通常 $\lambda$ は 1 2 2 であるので, $10 \AA$ 程度の トンネル間隙に対してトンネル電流は原子オーダの間 隙変化に対して極めて敏感となる.

図 2 に $(1)$ 式に基づいた間隙とトンネル電流の関係 を示す。図から,トンネル電流のサーボエラーが

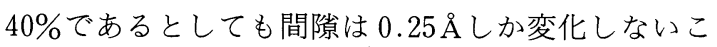
とがわかる. 通常, 原子スケールの観察では $10 \%$ 以 内に制御することが可能なので, 高さ方向の精度とし て $0.1 \AA$ 以下が得られる.また, 面分解能はトンネル 電流の放出面積に依存する.探針の先端の原子と隣の 原子との高さの差を $1 \AA$ とると, トンネル電流は先 端 1 個の原子からによるものが支配的になる.すなわ ち, 面分解能は原子 1 個程度となり, 我々が必要とす る原子オーダのアパーチャが実現できたことになる. 理論的には, Tersoff らにより面分解能 $\delta$ は次のよう に表される6).

$$
\delta \approx((s+R) \lambda)^{1 / 2}
$$

ただし， $R$ は先端原子の半径を示す.

\section{Si 表面観察}

写真 1 にシリコン (111) 表面への $\mathrm{Au}$ の結晶成長過 程の観察例7)8)を示す. 写真 1(a)のようにシリコン清 浄表面を超高真空内で形成し, この表面に $\mathrm{Au}$ 原子を 1 原子層以下あるいはそれ以上付着させ, アニール $\left(600^{\circ} \mathrm{C}\right)$ すると, 写真 $1(\mathrm{~b})$, (c) のような表面構造 (STM 像)を得る. 写真 1 ( b ) は Au 原子を約 0.3 原 子層つけた際の表面構造である.ステップに沿って $\mathrm{Au}$ 原子が並んでいる様子が観察され, シリコン基板 の単位格子の 5 倍の周期で並んでいる。一方, $\mathrm{Au}$ 原 子が成長していないテラスでは $7 \times 7$ の構造が観察さ れる.さらに, 平均 1 原子層以上付着すると, 写真 1 (c)のように, シリコン上の $\mathrm{Au}$ 原子配列は $\sqrt{3} \times \sqrt{3}$ 構造と変化する。 


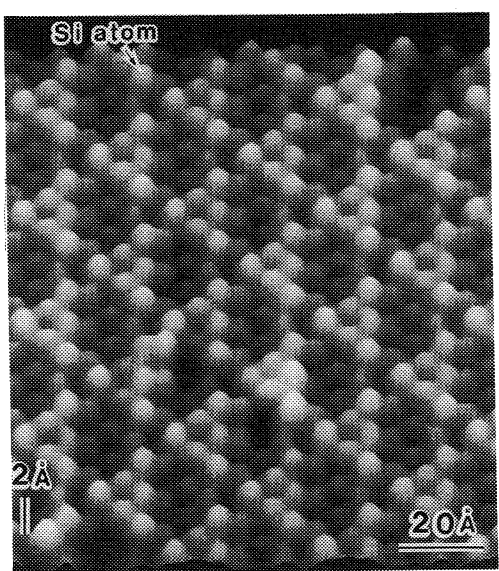

(a) $\mathrm{Si}$ (111)清浄表面

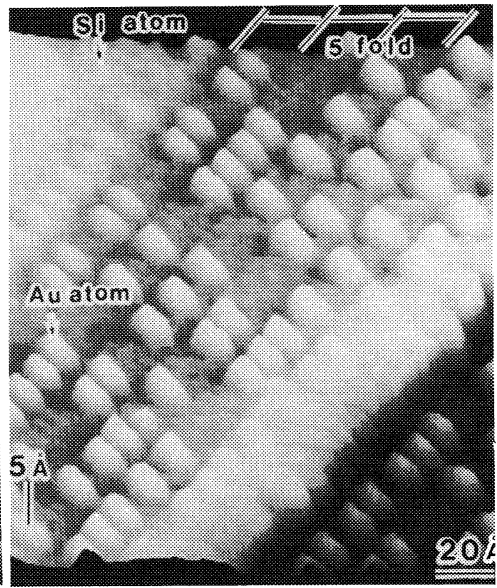

(b) $\mathrm{Si}(111)$ 上への $\mathrm{Au}$ 原子結晶成長 の初期 (0.3 原子層成長時)

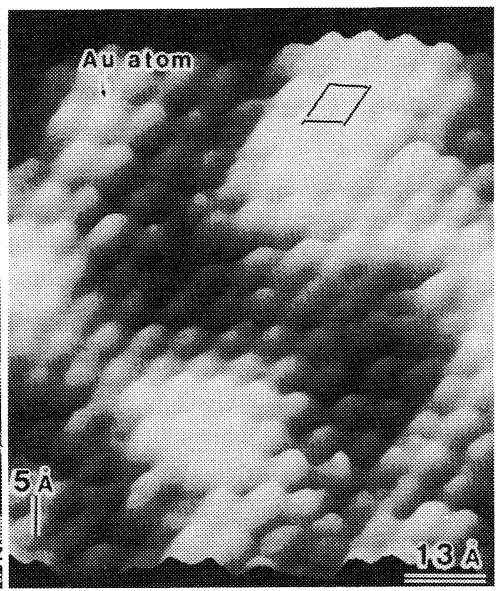

(c) $\mathrm{Si}$ (111) 上への $\mathrm{Au}$ 原子結晶成長 (1 原子層以上の成長時)

写真 $1 \mathrm{Si}$ (111)表面の原子オーダの観察とその場観察の一例

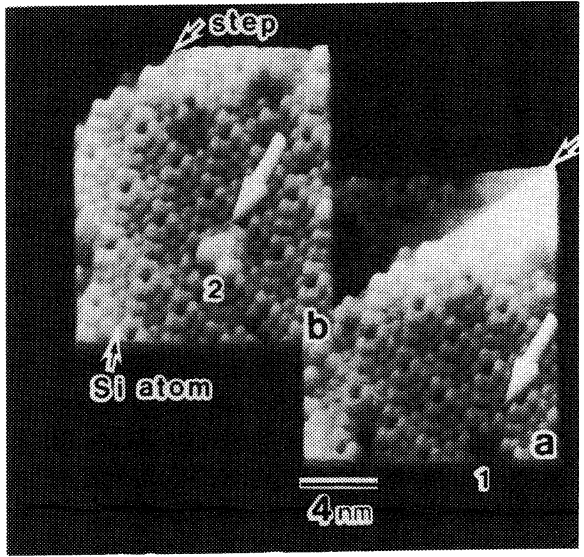

写真 $2 \mathrm{Si}(111)$ 清浄表面の動的観察例 (STM 像) ( $V=-2 \mathrm{~V}$ (試料), $I=0.1 \mathrm{nA},(\mathrm{a}):$ 欠陥 (1) 観察, ( b ) : 4 秒後, 吸着原子あるいは 分子 ( 2 ) 観察)

また, 写真 2 に清浄表面がどのように吸着物質で覆 われていくか観察した例を示す．ビデオレコーダによ り STM 連続像を記録した中から 2 コマを出力したも のである，写真のように，熱ドリフト(約 $10 \AA / \mathrm{s})$ が 観察されると共に, $\mathrm{Si}$ 吸着原子の欠落部 $(1)$ に原子 あるいは分子 (2)が吸着していく様子が捕えられてい る9).このような in-situでの観察は, 吸着現象, 結 晶成長やドライエッチング等のメカニズム解明のため の重要な手段となる. 最近では, 試料加熱中の $\mathrm{Si}$ 表 面の再配列, あるいは MBE 成長した際の成長過程な どの様子が観察でき, 新しい知見が見出されている.

\section{STM-TBI 複合計測（ポリシリコン中 の不純物分布) ${ }^{10)}$}

STM 観察に伴う特長的な計測に複合計測がある. これは従来技術である Auger 電子分光等の計測手段 より高分解能が期待できることを示す. 複合計測とし て, 走查トンネル分光STS (Scanning Tunneling Spectroscopy), 特定バイアスでの電流像 CITS (Current Imaging Tunneling Spectroscopy), トン ネル障壁像 TBI (Tunneling Barrier-height Imaging）技術がある。ここでは，動作原理等は省略する が，一例として TBIによるポリシリコン表面の観察 例を示す。

TBI は, 図3(a)のように不純物濃度によるバンド 構造の曲がりが, トンネル現象でのトンネル障壁に変 化を及ぼすことに注目したものである。これは，七素 をポリシリコンに注入すると, 伝導帯 (Conduction Band）が Fermi levelに近づき, 注入領域でのトンネ ル障壁が高くなる．トンネル電流測定の際, トンネル 障壁量を検出すれば不純物濃度分布の変化が測定でき る. TBI システムは, 通常のSTM システムに探針 の微小振動機能と電流変動量からのトンネル障壁検出 機能とを加えた構成である（図 $3(\mathrm{~b})$ ).これにより， STM像とTBI 像とを同時に観察することができ る.

試料は $n$ 型シリコンウェハ上に低圧 CVDにより形 成したポリシリコン膜を使用した。厚さは $0.25 \mu \mathrm{m}$ である.さらに,これに, 約 $0.5 \mu \mathrm{m}$ line and space 
のレジストパターンをマスクとして選択的に $80 \mathrm{keV}$ で $10^{14} \mathrm{~cm}^{-2}$ のAsイオン打込みし, $800^{\circ} \mathrm{C}, 30$ 分の アニーリングを行った.

写真 3 に観察結果を示す。(a )および ( b ) は同一場 所の STM 像, TBI 像を示す.（a )ではポリシリコ ンの結晶成長が見られず, 微細なグレイン構造のみ観 察される.これと同一視野をTBIで観察すると， (b)のような $\phi^{1 / 2}$ のコントラストを得ることができ る. 写真 3 より, 不純物濃度分布が line and space パ ターンで縦方向に伸びていることがわかる．図の明る い部分は $\psi$ が大きく不純物濃度が高い領域を, 暗い
部分は $\phi$ が小さく不純物濃度が低い領域を示してい る.すなわち, TBI 像は図 3 (a)のようにイオン打 ち込みによって発生した Conduction Bandの曲がり を相対的に捕え，それを画像化したものであるといえ る.

さらに, 写真 3 の注入部を拡大すると, グレイン境 界部の $\psi$ がグレイン内部の $\psi$ に比べて大きいことが わかった。これは, 比較的低温でのアニーリングのた め, グレイン境界部に電子が集まり $n$ 型化している こと(不純物の偏析)が推測される。これは, ポリシリ コン膜での不純物濃度の減少に伴う移動度の低下とい

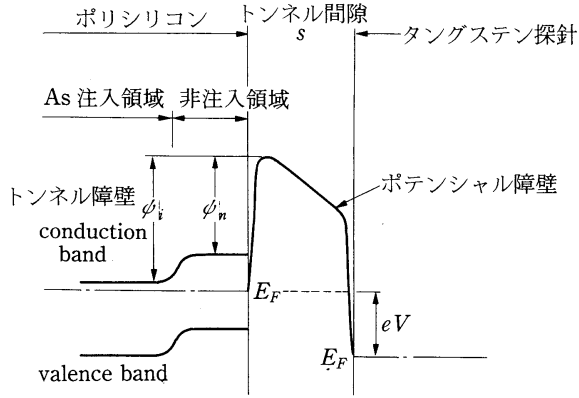

（a）不純物注入によるトンネル障壁の变化 (測定原理)

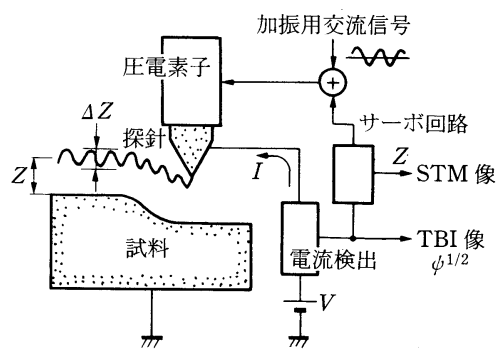

(b) STM を応用したTBI の原理構成 $\psi^{1 / 2} \sim(\Delta Z)^{-1}(\Delta I / I)$

図 3 TBI 原理説明図

(a)試料と探針が $10 \AA$ 程度近づいた際のトンネル障壁の模式図, (b)TBI 測定構成図

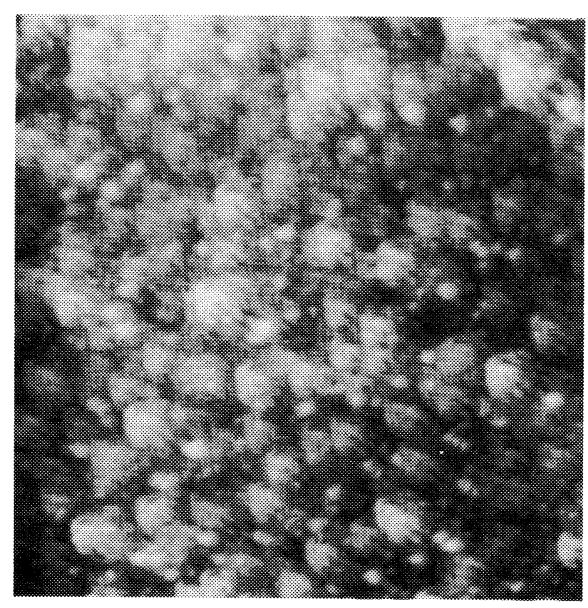

(a) STM 像

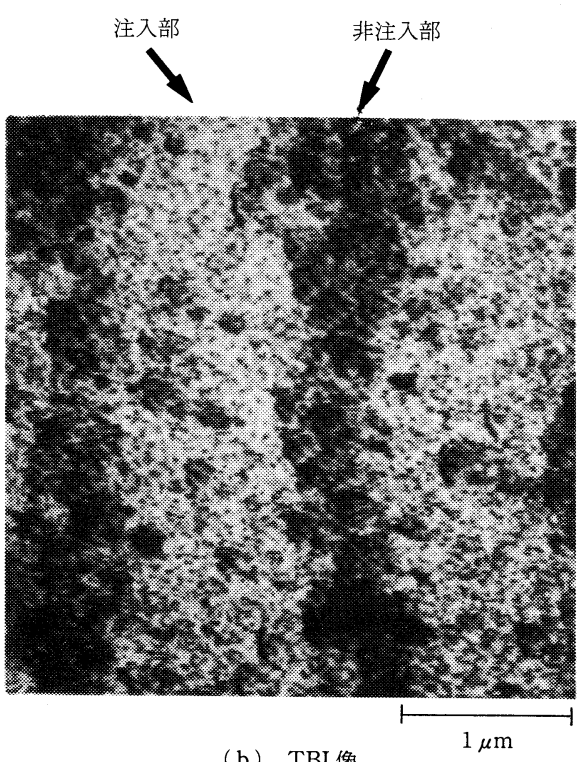

(b) TBI 像

写真 3 砒素 $(\mathrm{As})$ 部分注入したポリシリコン表面の観察例 (As 注入量 $: 10^{14} / \mathrm{cm}^{2}$,アニール $: 800^{\circ} \mathrm{C}, 30$ 分) 
表 1 レンズ光学システムと走查プローブ顕微鏡 (SPM) との比較

\begin{tabular}{c|c|c|c}
\hline \hline \multicolumn{2}{c|}{ レンズ光学システム } & \multicolumn{2}{c}{ 走查プローブ顕微鏡 } \\
\hline 計測機器 & 分解能 & 計測機器 & 分解能 \\
\hline $\mathrm{SEM}$ & $\sim 7 \AA$ & $\mathrm{STM}$ & $<2 \AA$ \\
\hline $\mathrm{SLM}$ & $\sim 0.2 \mu \mathrm{m}$ & $\mathrm{NFOS}$ & $20 \mathrm{~nm}$ \\
\hline $\mathrm{SAM}$ & $1 \mu \mathrm{m}$ & $\mathrm{TAM}$ & $<10 \mathrm{~nm}$ \\
\hline
\end{tabular}

SEM : 走查電子顕微鏡

SLM : 走查レーザ顕微鏡

SAM : 走查音響顕微鏡

TAM : トンネル音響顕微鏡

う電気特性の原因を初めて実空間で示している。ま た, この試料分析に限定すると, TBI 法は SIMS ( 2 次イオン質量分析）法と比較して, 2 桁前後, 分解能 および感度が高いことが確認されている。

\section{6. むす び}

最近, STM の欠点 (絶縁物が計測できない)を補う ため, あるいは, 新しい物理量を計測するため, 幾つ

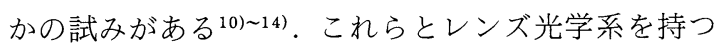
既存の顕微鏡技術とで比較すると，表 1 のようにな る.表より, STM 抢よびその関連技術は分解能の点 で従来技術に比べて 1 桁以上の向上が期待できる。ま た, STM 技術は真空中以外にガス中, 液体中 ${ }^{15)}$ でも 動作できることも見逃せない．

以上述べたように，STM および関連技術は，レン ズ光学を用いた顕微鏡技術より高分解能化が可能であ る.さらに,より微細なプローブ, アパーチャの開発 により高解像度の表面像が得られることが期待でき,
今後, 極めて注目される研究分野である.

(1991 年 12 月 27 日受付)

\section{〔参 考 文 献〕}

1) G. Binnig, H. Rohrer, Ch. Gerber, and E. Weibel: Phys. Rev. Lett., 50, 120 (1983)

2) R. D. Young, J. Ward and F. Scire: Phys. Rev. Lett., 27, 922 (1971) ; Rev. Sci. Instrum., 43, 999 (1972)

3) E. A. Ash and G. Nicholls: Nature, 237, 510 (1972)

4) U.Durig, D. Pohl and F. Rohner: IBM J. Res. Develop., 30, 478 (1986) ; J. Appl. Phys., 59, 3318 (1986)

5) J. G. Simmons: J. Appl. Phys., 34, 1973 (1963)

6) J. Tersoff and D. R. Hamamm: Phys. Rev., B31, 805 (1985)

7) T. Hasegawa, K. Takata, S. Hosaka and S. Hosoki : J. Vac. Sci. Technol., A8, 241 (1990)

8) T. Hasegawa, K. Takata, S. Hosaka and S. Hosoki : J. Vac. Sci. Technol., B9, 758 (1991)

9) S. Hosaka, T.Hasegawa, S. Hosoki and K. Takata: Appl. Phys. Lett., 57, 138 (1990)

10) S. Hosaka, K. Sagara, S. Hosoki, T. Hasegawa and K. Takata: J. Vac. Sci., Technol., A8, 270 (1990)

11) G. Binnig, C. F. Quate and Ch. Gerber: Phys. Rev. Lett., 56, 930 (1986) ; G. Binnig, Ch. Gerber, T. R. Albrecht and C. F. Quate: Europhys. Lett., 3, 1281 (1987)

12) Y. Martin and H. K. Wichramasinghe: J. Appl. Phys., 61, 4723 (1987)

13) K. Takata, T. Hasegawa, S. Hosaka, S. Hosoki and T. Komota: Appl. Phys. Lett., 55, 1718 (1989)

14) C. C. Williams, W. P. Hough and S. A. Rishton: Appl. Phys. Lett., 55, 203 (1989)

15）板谷, 菅原：表面科学，8，480(1987)

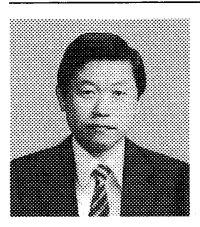

保圾 純势 昭和 46 年山梨大学工学部電 気工学科卒業. 同年, (株) 日立製作所中央研 究所饮社. 電子線, イオン線, 光を用いた 半導体リソグラフィ研究に従事した後, 昭和 60 年より, STM をはじめとする走査プロー グ顕微鏡の研究に従事し, 現在に至る.工学 博士. 